\title{
柔性载药纳米颗粒在毛细血管中输运特性的 数值模拟研究
}

间秀如 ${ }^{1}$, 乐恺 ${ }^{1,2^{*}}$, 张燕 ${ }^{1}$, 游宇 ${ }^{1,2}$, 张欣欣 ${ }^{1,2}$

1. 北京科技大学能源与环境工程学院, 北京 100083 ;

2. 北京科技大学顺德研究生院, 佛山 528399

*联系人, E-mail: yuekai@ustb.edu.cn

收稿日期: 2021-08-21; 接受日期: 2021-12-01; 网络版发表日期: 2022-06-10

国家自然科学基金(批准号: 51890891)和佛山市人民政府科技创新专项资金项目(批准号: BK20AE002)资助

摘要基于柔性纳米颗粒的载药系统由于其诸多优势而具有广泛的应用前景. 本文采用格子玻尔兹曼方法和浸 入边界法建立了柔性纳米颗粒和红细胞在毛细血管中的三维输运模型, 研究了柔性纳米颗粒的迁移机制与特性, 并分析了红细胞比容、变形能力及纳米颗粒刚度的影响规律. 结果表明, 在微血管中柔性纳米颗粒自身有向血管 中心迁移的趋势, 其径向迁移量随颗粒刚度的增强而减小. 红细胞的径向迁移运动及变形, 会导致纳米颗粒受排 挤而趋向血管壁面的无细胞层; 红细胞比容、变形能力及纳米颗粒刚度的增加, 能提高纳米颗粒的趋壁率. 在混 合颗粒输送方案中，颗粒间及颗粒与红细胞间的相互作用使得较低刚度颗粒的趋壁率减小并增加刚度较高颗粒 的趋壁率. 研究结果对纳米载体药物输送系统的设计具有理论指导意义.

关键词药物输运, 毛细血管, 柔性颗粒, 红细胞, 数值模拟

纳米药物因靶向性强、生物相容性好以及血液中 循环稳定等优点在肿瘤治疗方面展现出很大的临床应 用潜力. 研究表明, 柔性纳米颗粒在人体内具有较长的 循环时间，能快速穿过生物体内的黏液与肿瘤间质基 质，在肿瘤部位具有更高的积聚量; 而且由于巨噬细 胞不能吞噬非常柔软的目标，从而保护柔性纳米颗粒 不被清除 ${ }^{[1,2]}$. 近年来, 纳米载体材料研制技术的提升 使人们可以精确地调控纳米颗粒的变形刚度. 但在血 管中纳米颗粒的输运机制与运动规律的研究方面, 目 前大多着眼于刚性不可变形的载药颗粒. 针对柔性纳 米颗粒的输运特性有待进行深入研究.
纳米颗粒在微血管内的输运过程十分复杂, 受到 血液流动特性、血细胞作用、颗粒理化特性等多种因 素的影响. 为了探析其输运机制, 研究者们开展了一系 列理论与实验研究工作. 在颗粒性质方面, 研究了颗粒 的尺寸和形状对其在血流中输运的作用规律 ${ }^{[3 \sim 7]}$; 针对 血流特性，采用实验和数值模拟方法研究了微粒在不 同剪切速率血流中的输运过程 ${ }^{[8,9]}$. 由于血细胞的运动 对于维持人体正常生理活动至关重要, 因而有学者研 究了血小板与白细胞变形能力以及血流流速对相应血 细胞趋壁运动的影响规律 ${ }^{[10 \sim 12]}$. 此外，通过将血小板 假设为固体颗粒研究了血小板受力与红细胞比容之间

引用格式: 间秀如, 乐恺, 张燕, 等. 柔性载药纳米颗粒在毛细血管中输运特性的数值模拟研究. 中国科学: 生命科学, 2023, 53: 390-398 Yan X R, Yue K, Zhang Y, et al. Numerical simulation of transport of deformable drug nanoparticles in capillaries (in Chinese). Sci Sin Vitae, 2023, 53: 390-398, doi: 10.1360/SSV-2021-0314 
的相互关系 ${ }^{[11]}$ ，以及糖尿病病症情况下病变血小板与 正常血小板共存时血小板的运动行为 ${ }^{[13]}$. 血液中红细 胞特性会由于人体健康状况的不同而存在些许差别, 如有些肿瘤患者血液中红细胞数量明显小于健康人 群，正常人体的红细胞柔软易变形而肿瘤患者体内红 细胞变形能力降低等 ${ }^{[14 \sim 16]}$. 迄今还缺乏纳米颗粒刚度 及红细胞特性等因素对柔性纳米颗粒在毛细血管中输 运过程影响的研究.

本文结合格子玻尔兹曼方法与浸入边界法，对三 维毛细血管中柔性纳米颗粒的输运特性进行了数值模 拟研究. 通过分析血细胞作用下柔性颗粒在血液流场 中的运动轨迹，揭示柔性纳米颗粒在毛细血管中的输 运机制以及在输运过程中的变形特性, 研究红细胞比 容(hematocrit, Hct)、变形能力及其柔性纳米颗粒刚度 对纳米颗粒趋壁行为的影响规律.

\section{1 模型与方法}

\section{1 几何模型及参数}

本文建立的毛细血管中柔性纳米颗粒输运的模型 如图1所示. 其中, 毛细血管的长度 $L$ 为 $50 \mu \mathrm{m}$ 且直径 $H$ 为 $9 \mu \mathrm{m}$, 红细胞直径为 $7.82 \mu \mathrm{m}$, 柔性纳米颗粒的直径 为 $150 \mathrm{~nm}$ 且数目为 100 . 在初始时刻, 红细胞和柔性纳 米颗粒以随机的位置和方向分布在整个血管中. 血浆 动力黏度为 $1.34 \times 10^{-3} \mathrm{~Pa} \mathrm{~s}$, 密度为 $1.053 \mathrm{~g} / \mathrm{cm}^{3}$.

\section{2 基于格子玻尔兹曼方法的流动模型}

采用含有外力项的格子玻尔兹曼方法建立毛细血 管中的血液流动模型. 描述流体粒子运动的格子玻尔 兹曼方程为

$n_{i}\left(x+e_{i} \delta_{i}, t+\delta_{t}\right)-n_{i}(x, t)$

$=-\frac{1}{\tau}\left(n_{i}(x, t)-n_{i}^{\mathrm{eq}}(x, t)\right)+f_{i}(x, t)$,

式中, $e_{i}$ 为粒子的离散速度, $\delta_{t}$ 为时间步长, $\tau$ 为松他时 间, $n_{i}$ 为密度分布函数, $n_{i}^{\mathrm{eq}}$ 为对应的平衡态分布函数, $f_{i}$ 为施加在流体上的外力.

采用D3Q19模型, 各方向离散速度表达式为

$e_{i}=\left\{\begin{array}{l}(0,0,0), i=0 \\ ( \pm 1,0,0),(0, \pm 1,0),(0,0, \pm 1), i=1 \sim 6 \\ ( \pm 1, \pm 1,0),( \pm 1,0, \pm 1),(0, \pm 1, \pm 1), i=7 \sim 18\end{array}\right.$,
毛细血管中血液的宏观密度、速度求解公式为

$\rho(x, t)=\sum_{i} n_{i}(x, t), \rho(x, t) u=\sum_{i} n_{i}(x, t) e_{i}$,

式中, $\rho$ 为流体密度, $u$ 为流体速度.

\section{3 红细胞与纳米颗粒弹簧网络模型}

采用弹簧网络模型对红细胞与柔性纳米颗粒的运 动和变形过程进行数学描述. 红细胞在自然状态下为 具有一定可变形性的双凹面形, 柔性纳米颗粒初始形 状为球形, 红细胞及纳米颗粒弹簧网络模型节点数目 均为 393 个 $^{[17]}$, 如图1A所示. 物体表面被离散为多个节 点, 节点与节点之间由可伸缩的弹簧连接, 其拉伸力由 $F_{s}$ 表示; 通过控制相邻三角形网格之间的角度来维持 物体的初始形状，三角形网格所受弯曲力由 $F_{b}$ 表示; 为保持物体三角形网格面积守恒, 在每个节点上施加 收缩或扩张力 $F_{a l}$, 维持物体体积守恒的力由 $F_{v}$ 表示 ${ }^{[18]}$.

$$
\begin{aligned}
& F_{s}=k_{s} k\left(\frac{L}{L^{0}}\right) \frac{L-L^{0}}{L^{0}} n, F_{b}=k_{b} \frac{\theta-\theta^{0}}{\theta^{0}} n, \\
& F_{a l}=-k_{a l} \frac{S-S^{0}}{S} \omega, F_{v}=-k_{v} \frac{V-V^{0}}{V^{0}} S n,
\end{aligned}
$$

式中, $k_{s}, k_{b}, k_{a l}, k_{v}$ 分别表示拉伸系数、弯曲系数、面 积守恒系数和体积守恒系数; $L, \theta, S, V$ 分别表示相邻 两节点间的弹簧长度、三角形网格所成角度、面积和 物体体积; $L^{0}, \theta^{0}, S^{0}, V^{0}$ 表示不受外力时相邻两节点间 的弹簧长度、三角形网格所成角度、面积和物体体 积; $n$ 表示一个节点指向另一个节点的单位向量; $\omega$ 表示 从三角形网格质心指向三角形各顶点的单位向量. 上 式中的每一个系数值都会影响弹性物体的行为, 其中 健康红细胞系数值: $k_{s}=8 \times 10^{5} \mathrm{pN} / \mu \mathrm{m}, k_{b}=0.16 \mathrm{pN} \mu \mathrm{m}$, $k_{a l}=1 \times 10^{6} \mathrm{pN} / \mu \mathrm{m}, k_{v}=10 \mu \mathrm{Ns} / \mathrm{cm}^{[19]}$. 由于目前已研制 出多种柔性载药纳米颗粒, 如水凝胶纳米颗粒、纳米 胶束、纳米脂质体等, 分别通过调节交联剂比例、乳 化剂组分以及与亲水聚合物的比例等实现颗粒刚度的 调节，本文纳米颗粒模型的拉伸系数值在对应已制备 颗粒的弹性模量范围内选取 ${ }^{[20,21]}$, 并通过改变拉伸系 数 $k_{\mathrm{s}}$ 值来调节其刚度 ${ }^{[22]}$.

在模拟计算中, 血流的入口速度设为 $2 \mathrm{~mm} / \mathrm{s}^{[23,24]}$, 血管的进出口采用周期性边界条件，血管壁面采用标 准反弹格式处理. 本研究基于ESPResSo ${ }^{[19,25]}$ 软件平台 编程实现. 该平台是一种用于模拟软物质的开源科学 
A

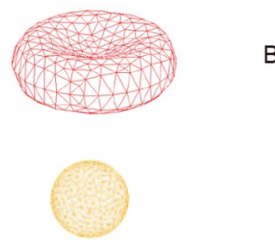

B

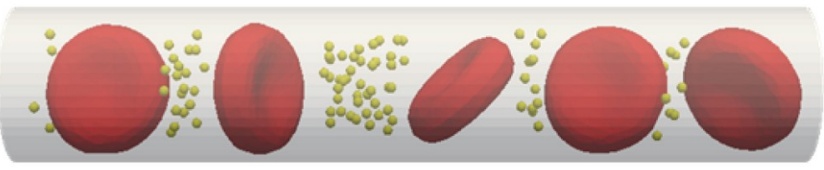

图 1 几何模型. A: 红细胞及柔性纳米颗粒模型; B: 毛细血管中红细胞及纳米颗粒输运模型(网络版彩图)

Figure 1 Geometric model. A: Model of RBC and deformable NP; B: model of RBCs and NPs transport in capillaries (color online)

软件, 可以有效地模拟微弹性物体. 它的特点是具有多 种形式的相互作用势，这为模拟不同级别的粗粒度模 型提供了可能性. 此外，它还可以处理静电学问题、 流体动力学分析以及电磁场分析等.

\section{4 红细胞与纳米颗粒运动模型}

采用浸入边界法 ${ }^{[18,26]}$ 处理流场中的浸没物体. 物 体的边界由物体表面上的点连接成的三角形网格表 示. 这些点在流固相互作用、弹性力学特性的影响下 在空间中移动. 对于浸入边界点的运动，使用牛顿运 动方程描述:

$m_{i b} \frac{\mathrm{d}^{2} X_{j}}{\mathrm{~d} t^{2}}=F_{j}$,

式中, $m_{i b}$ 为浸入边界点的质量, $X_{j}$ 为边界点的坐标, $F_{j}$ 为施加在特定浸入边界点的外力.

公式(1)和(5)分别描述流体和浸没物体的运动, 为 将流体与浸没物体运动耦合，本文对在流体中运动的 物体施加拖曳力，假设流体施加在浸入边界点上的力 与该点的速度 $v$ 和流体速度 $u$ 的差值成正比 ${ }^{[27]}$, 由公式 (6)表示:

$F_{j}=\xi(v-u)$,

式中, $\zeta$ 是摩擦系数 $\left(\mathrm{Nsm}^{-1}\right)$. 经文献 ${ }^{[17]}$ 校准, $\zeta=$ $1.76 \mathrm{Nsm}^{-1}$.

采用膜碰撞(membrane collision)势能函数来表示 红细胞之间的相互作用力 ${ }^{[28,29]}$, 由公式(7)表示:

$V(d)=a \frac{1}{1+e^{\text {nd }}}, d<d_{\text {cut }}$,

式中, $a$ 为换算参数 $(\mathrm{J}), d$ 和 $d_{\mathrm{cut}}$ 分别为细胞之间的距离 和相互作用势为零时的距离 $(\mathrm{m}), n$ 为比例系数 $\left(\mathrm{m}^{-1}\right)$, 表征细胞之间相互作用的强弱. 本文取 $a=5 \times 10^{-18} \mathrm{~J}$, $d_{\text {cut }}=0.5 \mu \mathrm{m}, n=2.0 \mu \mathrm{m}^{-1[30]}$.

纳米颗粒在毛细血管中的输运过程中, 颗粒与颗
粒、红细胞之间的相互作用不可忽略. 采用L-J势能函 数来表示纳米颗粒间的相互作用力 ${ }^{[31]}$, 由公式(8) 表示:

$V(r)=4 \varepsilon\left[\left(\frac{\sigma}{r}\right)^{12}-\left(\frac{\sigma}{r}\right)^{6}\right]$,

式中, $\varepsilon$ 为势井深度 $(\mathrm{J}), r$ 为纳米颗粒之间的距离 $(\mathrm{m}), \sigma$ 为颗粒间相互作用势能为零时的两体距离 $(\mathrm{m})$. 本文取 $\varepsilon=10^{-15} \mathrm{~J}, \sigma=0.2 \mu \mathrm{m}^{[32]}$.

采用Morse势能函数来表示纳米颗粒与红细胞之 间的相互作用力 ${ }^{[31]}$, 由公式(9)表示:

$V(r)=D_{e}\left[e^{-2 \beta\left(r-r_{\min }\right)}-2 e^{-\beta\left(r-r_{\min }\right)}\right]$,

式中, $D_{e}$ 为Morse势的肼深 $(\mathrm{J}), r$ 为纳米颗粒与红细胞之 间的距离 $(\mathrm{m}), r_{\mathrm{min}}$ 是其相互作用势能为零时的两体距 离 $(\mathrm{m}), \beta$ 为比例系数 $\left(\mathrm{m}^{-1}\right)$. 本文取 $D_{e}=4.1 \times 10^{-13} \mathrm{~J}, r_{\text {min }}$ $=0.5 \mu \mathrm{m}, \beta=2.0 \mu \mathrm{m}^{-1[32]}$.

采用软球(soft-sphere)势能函数来表示纳米颗粒/ 红细胞与血管壁之间的相互作用力 ${ }^{[28,29]}$, 由公式(10) 表示:

$V(d)=a d^{-n}, d<d_{\text {cut }}$,

式中, $a$ 为换算参数 $(\mathrm{J}), d$ 和 $d_{\mathrm{cut}}$ 分别为纳米颗粒 $/$ 红细胞 与血管壁之间的距离和相互作用势为零时的距离 $(\mathrm{m})$, $n$ 为比例系数 $\left(\mathrm{m}^{-1}\right)$. 本文取 $a=3.5 \times 10^{-19} \mathrm{~J}, d_{\mathrm{cut}}=0.5 \mu \mathrm{m}, n$ $=1.0 \mu \mathrm{m}^{-1[30]}$.

\section{2 结果}

\section{1 红细胞及柔性纳米颗粒的典型运动}

红细胞在毛细血管中会发生形状的改变并产生径 向迁移现象，图 $2 \mathrm{~A}$ 为健康红细胞在血管中运动时在不 同时刻的位置和形状. 可见, 红细胞在血管中会由血管 壁向血管中心迁移，且在运动过程中逐渐变成子弹头 

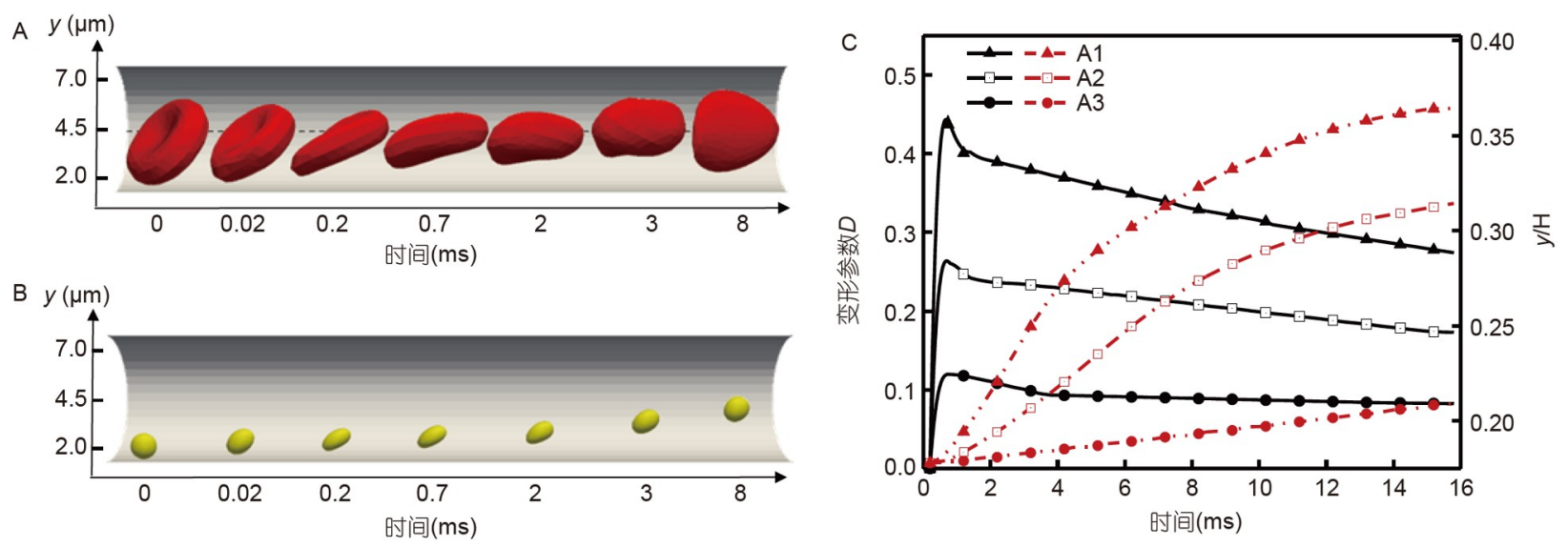

图 2 红细胞及柔性纳米颗粒的运动特性. A: 红细胞运动轨迹; $\mathrm{B}$ : 柔性纳米颗粒运动轨迹; $\mathrm{C}$ : 不同 $k_{s}$ 值下柔性纳米颗粒的变 形参数及径向迁移距离随时间的变化(网络版彩图)

Figure 2 Transport characteristics of RBCs and deformable NPs. A: Transport trajectories of RBCs; B: transport trajectories of deformable NPs: C: deformation parameters and lateral migration distance of deformable NPs versus time under different stretching constants (color online)

形状, 该结果与文献 ${ }^{[33,34]}$ 结果一致. 红细胞的径向迁移 现象造成血管中心处红细胞浓度大，且在血管壁面附 近形成无细胞层 ${ }^{[35,36]}$.

为了研究柔性纳米颗粒在血浆中的运动规律, 本 实验选取不同刚度值的纳米颗粒进行模拟分析, $k_{s}$ 取 值分别为 $\mathrm{A} 1: k_{s}=8 \times 10^{5} \mathrm{pN} / \mu \mathrm{m}, \mathrm{A} 2: 50 k_{s}, \mathrm{~A} 3: 100 k_{s}$. 图 $2 \mathrm{~B}$ 为 $k_{s}=8 \times 10^{5} \mathrm{pN} / \mu \mathrm{m}$ 的柔性纳米颗粒在不同时刻的 位置和形状, 与红细胞类似, 柔性纳米颗粒也有变形和 向血管中心迁移的趋势. 采用变形参数 $D=(L-S) /(L+S)$ 描述柔性纳米颗粒的变形程度, 其中 $L$ 和 $S$ 分别表示颗 粒的长半轴和短半轴 ${ }^{[37]}$. 对于未变形的颗粒, $L$ 与 $S$ 值 相等, 故 $D$ 值为零. $D$ 值越大, 表示颗粒变形越大. 图 $2 \mathrm{C}$ 为不同刚度柔性纳米颗粒的变形参数及径向迁移距离 随时间的变化. 可见, $k_{s}$ 值越大, 颗粒的变形程度越小, 且径向迁移距离也越小, 与文献 ${ }^{[38]}$ 的实验现象一致. 纳米颗粒变形的主要原因是壁面附近的剪切流动对纳 米颗粒表面不同位置处的曳力不同, 因而使纳米颗粒 产生变形, 颗粒的刚度越低, 变形程度越大. 颗粒的径 向迁移则是由于其所受流体曳力的合力在径向方向上 不为零造成的, 而变形越大的颗粒所受径向合力越大, 因而迁移量越大. 此外, 纳米颗粒的变形速度在初始阶 段很大, 这是由于初始阶段, 颗粒与血浆的速度差最 大, 所受的剪切力也最大, 在约 $t=0.8 \mathrm{~ms}$ 时变形程度达 到峰值, 而随后颗粒的变形程度逐渐下降, 这是由于随 着颗粒的径向迁移, 剪切力逐渐下降, 因此变形程度随 之下降.

\section{2 红细胞比容的影响}

正常人体毛细血管中的红细胞比容Hct范围在 $10 \% \sim 20 \%$ 之间 ${ }^{[39]}$, 纳米颗粒在毛细血管中的输运受到 红细胞运动的影响. 本节分析了 $\mathrm{Hct}=11 \%, 15 \%$ 及 $20 \%$ 三种情况下柔性纳米颗粒 $\left(k_{s}=8 \times 10^{5} \mathrm{pN} / \mu \mathrm{m}\right)$ 的输运特 性. 图 $3 \mathrm{~A}$ 所示为 $t=16 \mathrm{~ms}$ 时不同 Hct情况下红细胞和纳 米颗粒在血管中的分布, 可见纳米颗粒在输运过程中 会受到红细胞的排挤作用, 从而进入血管壁附近的无 细胞层, 以下称这种现象为纳米颗粒的趋壁行为. 颗 粒的趋壁行为是影响其与血管壁内皮细胞黏附、跨壁 进而到达肿瘤靶区组织成功与否的重要因素. 为了定 量研究该行为, 采用颗粒的趋壁率 $n_{\mathrm{p}}$ 来表征 ${ }^{[3]}, n_{\mathrm{p}}=$ $\left(n_{\mathrm{f}}(t)-n_{\mathrm{f}}(0)\right) / N$, 其中, $n_{\mathrm{f}}(t) 、 n_{\mathrm{f}}(0)$ 分别表示时刻 $t$ 和 $t=0$ 时位于无细胞层中的颗粒数, $N$ 表示血管中颗粒总数. 无细胞层的厚度 $\delta=R-R_{\text {core }}, R$ 和 $R_{\text {core }}$ 分别表示血管半 径和红细胞聚集区域半径 ${ }^{[13]}$.

$t=16 \mathrm{~ms}$ 时, 不同Hct情况下柔性纳米颗粒的趋壁 率及趋壁颗粒的平均径向迁移距离(向壁面方面迁移 为正)如图3B所示, 三种情况下颗粒趋壁率分别为 $12 \%, 27 \%, 37 \%$. 可见, Hct越大，颗粒径向迁移量越 大, 趋壁率越高, 这是由于红细胞对颗粒的排挤作用加 强导致的. 此时颗粒在血管不同径向位置区间内的分 布情况如图3C所示, Hct越小, 颗粒分布越向血管中心 集中, 颗粒浓度的峰值出现在靠近血管中心的位置; Hct越大，颗粒分布越向血管壁集中，颗粒浓度的峰值 
(a) $\mathrm{Hct}=0 \%$

(b) $\mathrm{Hct}=11 \%$

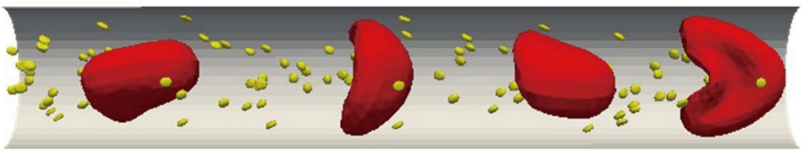

(c) $\mathrm{Hct}=15 \%$

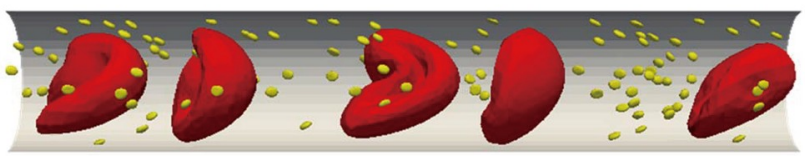

(d) $\mathrm{Hct}=\mathbf{2 0 \%}$

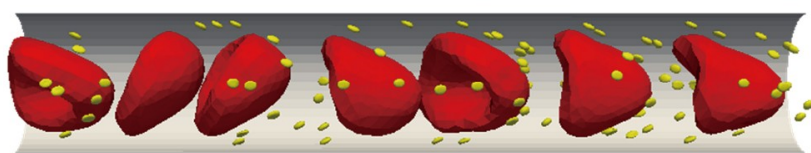

B

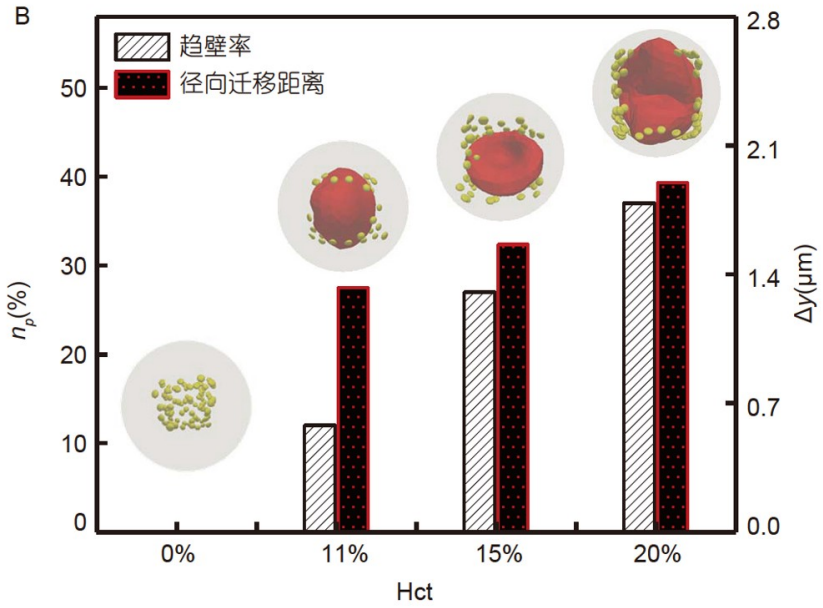

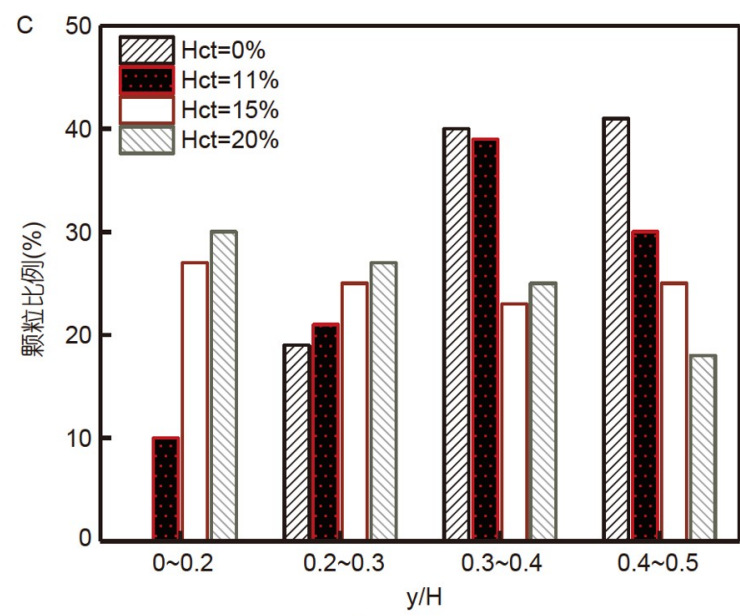

$(\mathrm{y} / \mathrm{H}=0$ 血管壁; $\mathrm{y} / \mathrm{H}=0.5$ 血管中心 $)$

图 3 Hct的影响. A: $t=16 \mathrm{~ms}$ 时红细胞和柔性纳米颗粒的分布; $\mathrm{B}: t=16 \mathrm{~ms}$ 时不同Hct下颗粒趋壁率及径向迁移距离(无细胞层 厚度 $\delta: \mathrm{Hct}=11 \%: 2.21 \mu \mathrm{m} ; \mathrm{Hct}=15 \%: 1.96 \mu \mathrm{m} ; \mathrm{Hct}=20 \%: 1.43 \mu \mathrm{m}$ ); C: $t=16 \mathrm{~ms}$ 时纳米颗粒在血管径向位置的分布(网络版彩图) Figure 3 Effect of blood hematocrit. A: Snapshots of RBCs and deformable NPs configuration in capillaries at $t=16$ ms; B: margination probability and lateral migration distance of NPs at different Hct at $t=16 \mathrm{~ms}$ (cell-free layer thickness $\delta: \mathrm{Hct}=11 \%: 2.21 \mu \mathrm{m} ; \mathrm{Hct}=15 \%: 1.96 \mu \mathrm{m}$; Hct=20\%: $1.43 \mu \mathrm{m})$; C: distribution of NPs in different lateral position of the capillary at $t=16 \mathrm{~ms}$ (color online)

出现在血管壁附近. 因而在体内给相同剂量的药物时, Hct较大的情况下，柔性纳米颗粒在靶区富集量将增 多, 有利于提高药物利用率.

\section{3 红细胞变形能力的影响}

不同健康状态的红细胞的变形能力不同，而红细 胞的变形也会对纳米颗粒的输运产生影响. 本节分析 $\mathrm{Hct}=15 \%$ ，柔性纳米颗粒 $k_{s}=8 \times 10^{5} \mathrm{pN} / \mu \mathrm{m}$ 时，红细胞 变形能力对柔性纳米颗粒输运的影响. 细胞的变形 能力主要由拉伸系数 $k_{s}$ 值决定, 以下分析中 $k_{s}$ 的取值分
别为 $8 \times 10^{5} \mathrm{pN} / \mu \mathrm{m}$ (健康红细胞，以下用 $\mathrm{soft}$ 表示)、 $40 \times 10^{5} \mathrm{pN} / \mu \mathrm{m}(\mathrm{stiff}) 、 400 \times 10^{5} \mathrm{pN} / \mu \mathrm{m}(\text { rigid })^{[15]}$.

图4为不同红细胞变形能力情况下, 柔性纳米颗粒 和红细胞在毛细血管中的输运模型. 以变形参数 $D$ (计 算方法同纳米颗粒)表征红细胞的变形程度, 图 $5 \mathrm{~A}$ 为 不同变形能力的红细胞 $D$ 值随时间的变化曲线, 随着 $k_{\mathrm{s}}$ 值增大, 变形程度减小, 且红细胞的变形随时间先迅速 增加后缓慢减小, 这是由于随着流体开始流动, 红细胞 与血浆的速度差较大, 所受的剪切力也较大, 细胞在产 生明显的径向迁移前迅速改变了形状，变形程度在短 

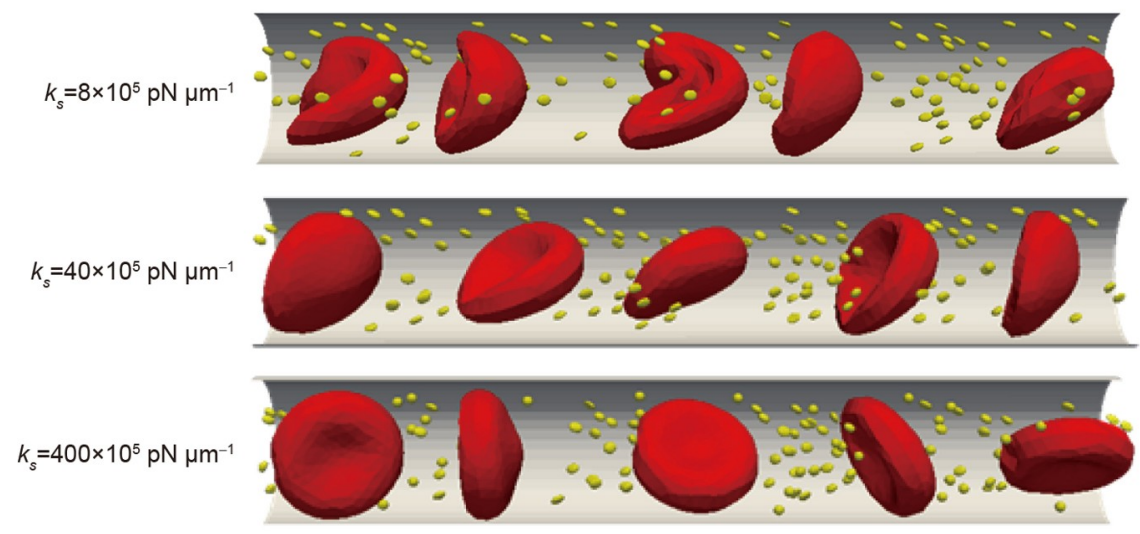

图 4 不同红细胞变形能力下柔性纳米颗粒在毛细血管中的输运模型(无细胞层厚度 $\delta: k_{s}=8 \times 10^{5} \mathrm{pN} / \mu \mathrm{m}: 1.96 \mu \mathrm{m} ; k_{s}=40 \times$ $10^{5} \mathrm{pN} / \mu \mathrm{m}: 1.8 \mu \mathrm{m} ; k_{s}=400 \times 10^{5} \mathrm{pN} / \mu \mathrm{m}: 1.54 \mu \mathrm{m}$ )(网络版彩图)

Figure 4 Transport model of deformable NPs in capillaries under different deformability of RBCs (cell-free layer thickness $\delta: k_{s}=8 \times 10^{5} \mathrm{pN} / \mu \mathrm{m}$ : $\left.1.96 \mu \mathrm{m} ; k_{s}=40 \times 10^{5} \mathrm{pN} / \mu \mathrm{m}: 1.8 \mu \mathrm{m} ; k_{s}=400 \times 10^{5} \mathrm{pN} / \mu \mathrm{m}: 1.54 \mu \mathrm{m}\right)$ (color online)
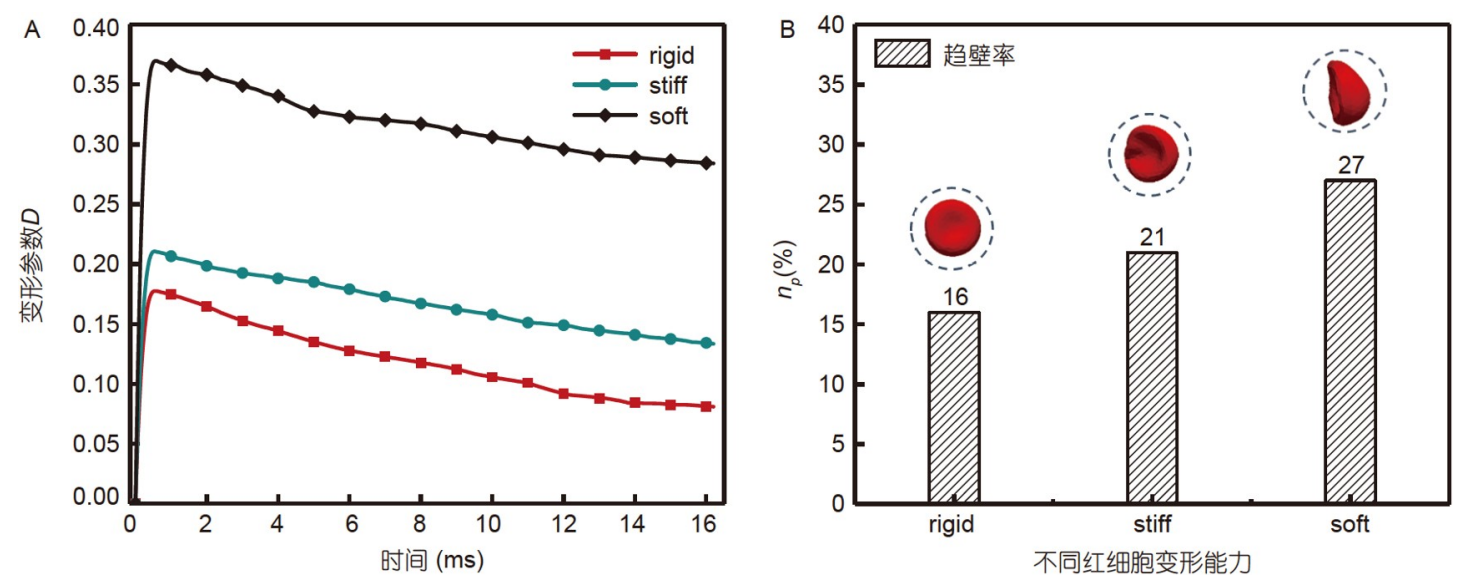

图 5 红细胞变形能力的影响. A: 红细胞的变形参数随时间的变化; $\mathrm{B}$ : 不同红细胞 $k_{s}$ 值下柔性纳米颗粒的趋壁率(网络版 彩图)

Figure 5 Effect of deformability of RBCs. A: Deformation parameters of RBCs versus time; B: margination probability of deformable NPs at different stretching constants of RBCs (color online)

时间内达到峰值. 在之后的运动中, 随着细胞向血管中 心区域运动, 其所受的剪切力减小, 变形减小. 这与 2.1 节所述的柔性纳米颗粒在血浆中的变形规律一致. 图 $5 \mathrm{~B}$ 为不同红细胞变形能力情况下柔性纳米颗粒的趋 壁率, 对应红细胞 $k_{s}=400 \times 10^{5} \mathrm{pN} / \mu \mathrm{m}, 40 \times 10^{5} \mathrm{pN} / \mu \mathrm{m}$, $8 \times 10^{5} \mathrm{pN} / \mu \mathrm{m}$ 时, 纳米颗粒的趋壁率 $n_{\mathrm{p}}$ 分别为 $16 \%$, $21 \%, 27 \%$, 即随着红细胞变形能力增大, 柔性纳米颗 粒的趋壁率有所增加. 变形能力较弱的红细胞在运动 过程中依然呈现双凹面形状，径向集中趋势不明显且 细胞间距较大，从而颗粒趋向于位于细胞之间的间隙 中, 趋壁趋势微弱; 而随着红细胞变形能力的增大, 细 胞向管轴区域集中现象明显，因而占据的血管中心区
域增大, 颗粒到达无细胞层的概率增加.

\section{4 柔性纳米颗粒刚度的影响}

为分析柔性纳米颗粒的刚度对于其在毛细血管中 输运的影响, 本实验研究了 $\mathrm{Hct}=15 \%$ 时, 刚度分别为 2.1 节所述A1，A2，A3的纳米颗粒在血管中的输运特 性. 图6A为三种情况下柔性纳米颗粒的趋壁率随时间 的变化. 可见, 纳米颗粒的趋壁率随时间逐渐增加, 且 在同一时刻, 颗粒的刚度越高, 其趋壁率越大, 当 $t=$ $16 \mathrm{~ms}$ 时, 三种刚度的颗粒趋壁率分别达到 $27 \%, 32 \%$, $40 \%$. 这是由于刚度较高的颗粒变形程度小, 因而径向 方向所受合力较小, 向血管中心的迁移距离也较小, 因 

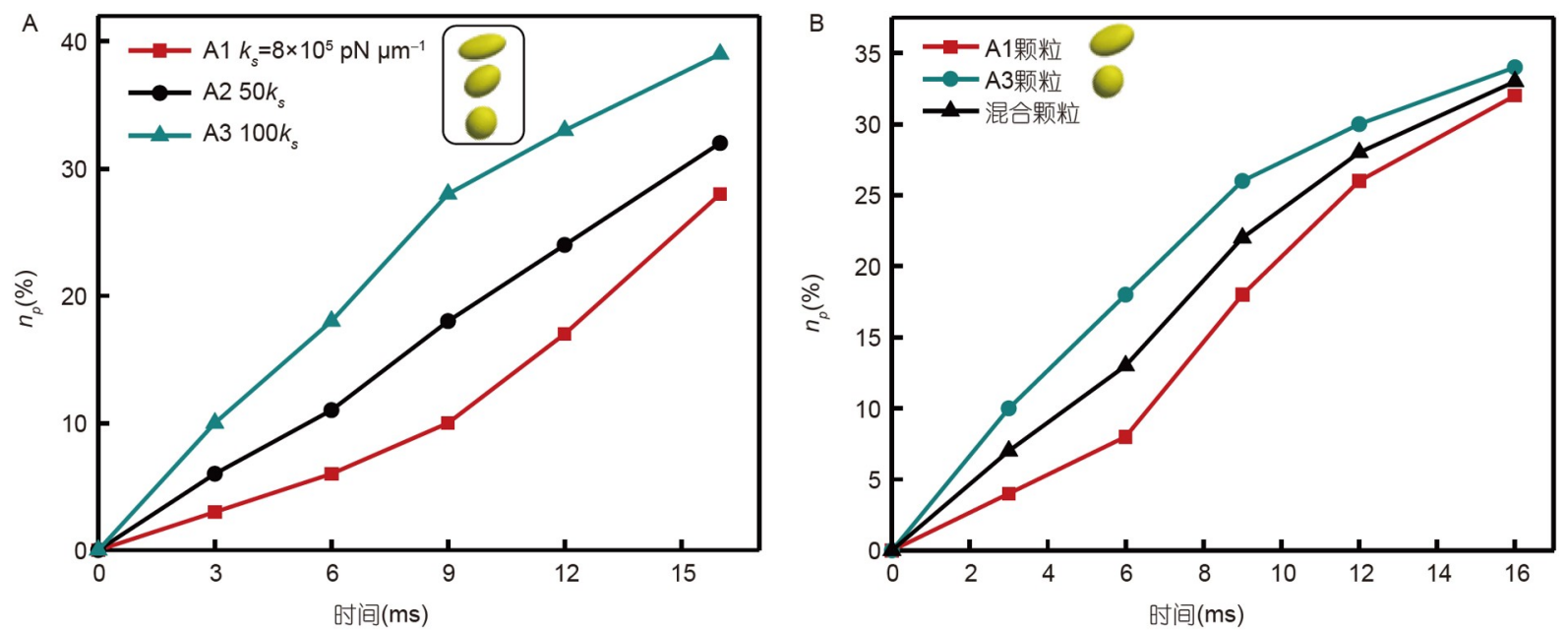

图 6 柔性纳米颗粒趋壁率随时间的变化. A: A1, A2, A3纳米颗粒; B: 混合纳米颗粒(网络版彩图)

Figure 6 Margination probability of deformable NPs versus time. A: A1, A2, A3 NPs; B: mixed NPs (color online)

此更容易趋壁. 刚度较低的纳米颗粒则趋壁程度较低, 说明在血液中的循环时间较长，该结果与实验结论一 致 ${ }^{[40]}$.

此外，为探寻不同刚度纳米颗粒共存时其输运特 性进而为临床药物递送提供指导依据，本节还分析了 毛细血管中同时存在A1，A3两种颗粒(数量各占 $50 \%$ ) 时的输运规律，颗粒趋壁率随时间的变化情况如图6B 所示，三条曲线分别表示两种颗粒各自的趋壁率以及 总趋壁率. 与毛细血管中只有一种颗粒的情况相比, 两种刚度的颗粒共存时其总趋壁率介于两种颗粒单独 存在时之间, 而刚度较低的颗粒趋壁率有所降低, 刚度 较高的颗粒趋壁率有所升高，这可能是由于异质颗粒 间的碰撞及颗粒与红细胞间的相互作用造成的 ${ }^{[4]}$. 此 外，两种颗粒趋壁率的差异随时间逐渐变小. 可见，两 种刚度的颗粒共存于毛细血管中时，趋壁行为不同于 两种颗粒单独存在的情况，因而采用混合颗粒的方式 可以调节纳米颗粒在毛细血管中的输运特性.

\section{3 讨论}

本文采用三维格子玻尔兹曼方法和浸入边界法建
立了柔性纳米颗粒在毛细血管中的输运模型, 研究了 柔性纳米颗粒的输运机制, 以及红细胞比容、变形能 力和纳米颗粒刚度对其输运的影响规律, 主要结论 如下.

(1) 柔性纳米颗粒自身在毛细血管中由于不同位 置处所受的曳力不同而发生形状的改变, 且流体曳力 的合力在其径向方向上不为零导致颗粒向血管中心迁 移. 刚度越高, 径向迁移距离越小. 在纳米颗粒和红细 胞存在的毛细血管中，颗粒受红细胞排挤而向壁面附 近的无细胞层迁移.

（2）红细胞比容、变形能力以及柔性纳米颗粒的 刚度均会影响纳米颗粒的输运过程. 随着红细胞比容 增加，颗粒径向迁移距离增大，纳米颗粒的趋壁率增 加且浓度的峰值向壁面靠近. 红细胞变形能力的增加 导致颗粒进入无细胞层的比例增加. 随着柔性纳米颗 粒的刚度增大，颗粒径向迁移距离减小，趋壁率有所 增加. 两种刚度的颗粒共存于毛细血管中时, 颗粒总 趋壁率介于两种颗粒单独存在时之间，且两种颗粒趋 壁率的差异随时间逐渐变小，体现出柔性纳米颗粒变 形能力对其输运特性的影响. 本文研究结果可以为柔 性纳米颗粒的临床应用提供一定的理论依据.

\section{参考文献}

1 Hartmann R, Weidenbach M, Neubauer M, et al. Stiffness-dependent in vitro uptake and lysosomal acidification of colloidal particles. Angew Chem Int Ed, 2015, 54: 1365-1368 
$2 \mathrm{Yu}$ M, Xu L, Tian F, et al. Rapid transport of deformation-tuned nanoparticles across biological hydrogels and cellular barriers. Nat Commun, 2018, 9: 2607

3 Ye H, Shen Z, Li Y. Shear rate dependent margination of sphere-like, oblate-like and prolate-like micro-particles within blood flow. Soft Matter, 2018, 14: 7401-7419

4 Mehrabadi M, Ku D N, Aidun C K. Effects of shear rate, confinement, and particle parameters on margination in blood flow. Phys Rev E, 2016, 93: 023109

5 Ta H T, Truong N P, Whittaker A K, et al. The effects of particle size, shape, density and flow characteristics on particle margination to vascular walls in cardiovascular diseases. Expert Opin Drug Deliv, 2018, 15: 33-45

6 Müller K, Fedosov D A, Gompper G. Margination of micro- and nano-particles in blood flow and its effect on drug delivery. Sci Rep, 2015, 4: 4871

7 Albanese A, Tang P S, Chan W C W. The effect of nanoparticle size, shape, and surface chemistry on biological systems. Annu Rev Biomed Eng, 2012, 14: 1-16

8 Krüger T. Effect of tube diameter and capillary number on platelet margination and near-wall dynamics. Rheol Acta, 2016, 55: 511-526

9 Fish M B, Fromen C A, Lopez-Cazares G, et al. Exploring deformable particles in vascular-targeted drug delivery: softer is only sometimes better. Biomaterials, 2017, 124: 169-179

10 Fedosov D A, Fornleitner J, Gompper G. Margination of white blood cells in microcapillary flow. Phys Rev Lett, 2012, 108 : 028104

11 AlMomani T, Udaykumar H S, Marshall J S, et al. Micro-scale dynamic simulation of erythrocyte-platelet interaction in blood flow. Ann Biomed Eng, 2008, 36: 905-920

12 Vahidkhah K, Diamond S L, Bagchi P. Platelet dynamics in three-dimensional simulation of whole blood. Biophys J, 2014, 106: 2529-2540

13 Chang H Y, Yazdani A, Li X, et al. Quantifying platelet margination in diabetic blood flow. Biophys J, 2018, 115: 1371-1382

14 Xu J, Wang X L, Liu J Q, et al. Effect of red blood cell mechanical properties on platelet near wall motion (in Chinese). Chin J Theor Appl Mech, 2013, 45: 974-981 [许菁, 王骁龙, 刘笉乔, 等. 红细胞力学特性对血小板近壁运动的影响. 力学学报, 2013, 45: 974-981]

15 Gutierrez M, Fish M B, Golinski A W, et al. Presence of rigid red blood cells in blood flow interferes with the vascular wall adhesion of leukocytes. Langmuir, 2018, 34: 2363-2372

16 Lin L, Ba Y Y, Lv P, et al. Red blood cell deformability and its significance in the study of hemorheology (in Chinese). J Inner Mongol Univ Natl (Nat Sci Ed), 2006, 4: 430-432 [林琳, 巴燕燕, 吕品, 等. 红细胞变形性及其在血液流变学研究中的意义. 内蒙古民族大学学报(自然科学 版), 2006, 4: 430-432]

17 Bušík M., Cimrák I., The calibration of fluid-object interaction in immersed boundary method. EPJ Web Conf, 2017, 143: 02013

18 Cimrák I, Gusenbauer M, Jančigová I. An ESPResSo implementation of elastic objects immersed in a fluid. Comput Phys Commun, 2014, 185: 900-907

19 Limbach H J, Arnold A, Mann B A, et al. ESPResSo - an extensible simulation package for research on soft matter systems. Comput Phys Commun, 2006, 174: 704-727

20 Hui Y, Yi X, Hou F, et al. Role of nanoparticle mechanical properties in cancer drug delivery. ACS Nano, 2019, 13: 7410-7424

21 Liu L, Jin P, Zhang G L, et al. Research progress on nanoparticles for drug carriers (in Chinese). Mod Chem Ind, 2005, 25: 106-110 [刘亮, 晋平, 张国亮, 等. 用于药物载体的纳米粒子的研究进展. 现代化工, 2005, 25: 106-110]

22 Ye H, Shen Z, Li Y. Interplay of deformability and adhesion on localization of elastic micro-particles in blood flow. J Fluid Mech, 2018, 861: 5587

23 Chen C H. Fundamental studies on the rheological properties of red blood cells in capillaries (in Chinese). Dissertation for Master's Degree. Jinan: Shandong University, 2012 [陈春晖. 毛细血管中红细胞流变特性的基础性研究. 硕士学位论文. 济南: 山东大学, 2012]

24 Cantor L B, Harris A, Wolf S, et al. Measurement of superficial optic nerve head capillary blood velocities by scanning laser fluorescein angiography. J Glaucoma, 1994, 3: S61???64

25 Arnold A, Lenz O, Kesselheim S, et al. Espresso 3.1: molecular dynamics software for coarse-grained models. In: Griebel M, Schweitzer M, eds. Meshfree Methods for Partial Differential Equations VI. Lecture Notes in Computational Science and Engineering. Berlin, Heidelberg: Springer. 2013: $1-23$

26 Mittal R, Iaccarino G. Immersed boundary methods. Annu Rev Fluid Mech, 2005, 37: 239-261

27 Ahlrichs P, Dünweg B. Lattice-Boltzmann simulation of polymer-solvent systems. Int J Mod Phys C, 1998, 09: 1429-1438 
Cimrák I, Jančigová I. Computational Blood Cell Mechanics: Road Towards Models and Biomedical Applications. Boca Raton: CRC Press, 2020

Smiešková M, Bachratá K. Validation of Bulk Properties of Red Blood Cells in Simulations. In: 2019 International Conference on Information and Digital Technologies (IDT). Zilina. 2019. New York: IEEE, 2019. 417-423

Bachratý H, Kovalčíková K, Bachratá K, et al. Methods of exploring the red blood cells rotation during the simulations in devices with periodic topology. In: 2017 International Conference on Information and Digital Technologies (IDT). Zilina. 2017. New York: IEEE, 2017. 36-46 Yue K, You Y, Yang C, et al. Numerical simulation of transport and adhesion of thermogenic nano-carriers in microvessels. Soft Matter, 2020, 16: $10345-10357$

32 Tan J, Thomas A, Liu Y. Influence of red blood cells on nanoparticle targeted delivery in microcirculation. Soft Matter, 2011, 8: 1934-1946 Pozrikidis C. Axisymmetric motion of a file of red blood cells through capillaries. Phys Fluids, 2005, 17: 031503 Heart Circ Physiol, 2001, 281: H629-H636

Bagchi P. Mesoscale simulation of blood flow in small vessels. Biophys J, 2007, 92: 1858-1877

Coupier G, Kaoui B, Podgorski T, et al. Noninertial lateral migration of vesicles in bounded Poiseuille flow. Phys Fluids, 2008, 20: 111702

Navidbakhsh M, Rezazadeh M. A computational study of a capsule lateral migration in microchannel flow. Acta Mech Sin, 2013, 29: 513-525

Karnis A, Goldsmith H L, Mason S G. The kinetics of flowing dispersions. J Colloid Interface Sci, 1966, 22: 531-553

Fung Y. Biomechanics: Circulation. New York: Springer, 1997

Anselmo A C, Mitragotri S. Impact of particle elasticity on particle-based drug delivery systems. Adv Drug Deliv Rev, 2017, 108: 51-67

Kumar A, Graham M D. Segregation by membrane rigidity in flowing binary suspensions of elastic capsules. Phys Rev E, 2011,84 : 066316

\title{
Numerical simulation of transport of deformable drug nanoparticles in capillaries
}

\author{
YAN XiuRu ${ }^{1}$, YUE Kai ${ }^{1,2}$, ZHANG Yan ${ }^{1}$, YOU Yu ${ }^{1,2} \&$ ZHANG XinXin ${ }^{1,2}$ \\ 1 School of Energy and Environmental Engineering, University of Science and Technology Beijing, Beijing 100083, China; \\ 2 Shunde Graduate School of University of Science and Technology Beijing, Foshan 528399, China
}

Drug delivery system based on deformable nanoparticles (NPs) has potential for diagnosis and therapy due to its unique advantages. A three-dimensional transport model of deformable NPs and red blood cells (RBCs) in capillaries was established using the lattice Boltzmann method and immersed boundary method. The migration mechanism and deformation characteristics properties of NPs were investigated and the effects of hematocrit, deformability of RBCs, and stiffness of NPs were analyzed. Results show that deformable NPs tended to migrate to the capillary center in blood flows, and the lateral migration distance decreased with the increase of the stiffness of NPs. The radial migration and deformation of RBCs led to the migration of deformable NPs towards the acellular layer of blood vessel wall. The increases of hematocrit, deformability of RBCs, and stiffness of NPs can increase the NPs margination probability. For the therapeutic strategy based on mixed NPs, the margination probability of the NPs with lower stiffness decreased due to the NP-NP and NP-RBC interactions whereas that of the NPs with higher stiffness increased. The results can provide guidance to the design of nano-drug carriers for biomedical applications.

\section{drug delivery, capillaries, deformable particles, red blood cells, numerical simulation}

doi: $10.1360 / \mathrm{SSV}-2021-0314$ 